\title{
Effect of Cutting Conditions and Cooling Fluid on the Surface Roughness of AA2024 in Turning Process
}

\author{
Wafa Mahdi Jodia \\ Department of Metallurgical Engineering, College of Materials Engineering, \\ University of Babylon, Babylon, Iraq. \\ wafamahdi55@yahoo.com
}

\begin{abstract}
This research studied the effect of cutting conditions and cooling fluid on the surface roughness for Aluminum alloy 2024 worked by a turning machine in dry and wet cutting cases. The work was performed with different spindle speeds and feed rates with a constant depth of cutting. The cooling fluid used in this work was emulsion water (water/oil). The results proved that the cutting conditions and the coolant have a significant effect to maintain the surface with a least roughness (Ra) possible even without the use of the coolant. On the other hand, the results showed that the feed rate was very effective factor compared to the spindle speed.
\end{abstract}

Key words: Surface roughness, Turning process, Cutting conditions and Cooling fluid.

\section{Introduction}

Cutting fluids are used to minimize the friction and then the heat generated during cutting operations, they are also used to improve the surface finish and increase tool life. There are two types of liquid cutting fluids: straight cutting oil and soluble oil. For high speed metal cutting operations the use of water based fluids is better than the oil based because of its coolant and has twice specific heat from the other cutting fluid [1]. When the manufacturing process is used, it is impossible to get a perfectly smooth surface. The irregularities on the surface are in the form of hills, spacing and valleys. These forms are termed as surface roughness, finish, texture or quality. On the other hand, the roughness can be defined as irregular deviations on a scale and can be expressed in term of its height, its width and distance on the measuring surface [2]. Two types of commercial vegetable oils: mineral oil and sunflower oil which were used to fined thrust force and surface roughness during drilling the 304 austenitic stainless steel with the HSSE tool. The vegetable oils reduced thrust force and fine surface finish in various feed rates and cutting speeds [3]. A nickel-based alloy was turned by a turning machine at various cutting speeds and dry conditions, the result showed the effect of the cutting speed with the dry process on the surface roughness [4]. Aluminum alloy 6061operated for improved surface quality by controlling the relationship between the feed and surface quality. The surface roughness limit was reached when the feed up and increase surface speed into the roughness range to maximize output [5]. This study investigated the effect of cutting conditions on the surface roughness for aluminum and stainless steel by a turning process. The minimum roughness in the aluminum is found at a speed lower than the stainless steel with the same feed rate. Finally, the surface finish became minimal when the surface roughness increased [6]. This research focused on the effect of cutting fluid on the surface roughness by using different cutting speeds with 
constant other parameters and used five types of cutting fluids with dry cutting case. The study proved that the standard fluid gives better values and then sun flower oil while the air stream doesn't give the results and the best surface roughness was obtained when high cutting speed with all types of cutting fluid [7]. The effect of main parameters such as speed, feed rate and depth of cut were investigated on the surface roughness in Al-2024, is found that the surface roughness decreases with the increase of the speed, but it increases with the increase of the feed rate and the depth of the cut [8]. HSS cutting tool and coolant flow rate with cutting conditions(feed rate, cutting speed and constant depth of cut) were established to convert the aluminum alloy to high quality to finish the surface with the minimum quantity of coolant [9]. Different cutting parameters like: cutting speed, depth of cut, feed and use of cutting coolant were indicated to measure the surface roughness for steel turned components with carbide tool by using the computer numerically controlled (CNC) turning machine, the results showed that the surface roughness decreased by the increase of the cutting speed and with the use of the coolant while it was lower when the depth of cut was high. At the end, it can be said that the surface roughness in the CNC machine was less than that of another traditional machine [10]. Two types of cutting fluid (web oil and oil soluble oil) were used with different cutting speeds and feed rates. The results showed the web oil worked only at low cutting speeds and feed rates while the soluble oil gives action in high cutting speeds and feed rates. Therefore, the cutting fluids differed from the performance of the machining processes due to their lubrication and chip motive [11].

This paper will concentrated on the effect of cutting conditions such as spindle speed, feed rate and constant depth of cut for the aluminum alloy on the surface roughness of the turning machine in the case of dry and wet cutting by using emulsion water (water/oil) as a cooling fluid..

\section{Experimental Part}

In this paper, twenty-five samples with $25 \mathrm{~mm}$ diameter and $60 \mathrm{~mm}$ length were used from Aluminum alloy 2024. The chemical composition of alloy was indicated in table (1). Figure (1) shows the samples that have been machined in dry and wet cutting cases. The process was performed on a lathe machine (ZMM Bulgaria, modelCU500with 21speed, 20-2000r.p.m and 7.5Kwat motor capacity) by using the high speed steel (HSS) cutting tool. Three parameters of cutting conditions have been taken: spindle speed, feed rate and constant depth of cut. Cooling fluid used was emulsion water contained (water and engine oil). Its properties are showed in table (2).

Surface roughness Tester HER210 Model was used to measure the surface roughness ( $\mathrm{Ra})$ with accuracy $0.05 \mu \mathrm{m}$. Device shape is shown in figure (2). Three points have been taken from different locations on the operating surfaces and then the rate is taken in dry and wet cutting cases.

\section{Results and Discussion}

Surface roughness $(\mathrm{Ra})$ values of the Aluminum alloy measured by operated surfaces conforming for all experimental work are explain during graphics in dry and wet cutting cases. 


\subsection{Dry cutting case:}

From Figure (3) it can be observed that the surface roughness increases with the increase of the feed rate at constant spindle speed, for example, at the same speed, (Ra) starts growing to reach its highest level, so on for the other spindle speed. However at the constant feed rate, the surface roughness decreases with the increase of the spindle speed, for example, at the same feed rate, ( $\mathrm{Ra}$ ) begins to decrease reaching to the lowest value, this indicates in Figure (4). At the end in this case, the minimum (Ra) became $(2.217 \mu \mathrm{m})$ in less feed rate $(\mathrm{f}=0.2 \mathrm{~mm} / \mathrm{rev})$ and high spindle speed $(\mathrm{N}=550 \mathrm{rpm})$, this agrees with reference [6], included that feed rate was a very effective factor on the surface roughness and then spindle speed, such as in reference [12].

\subsection{Wet cutting case:}

By using cooling fluid and from Figure (5) it can be found that the surface roughness values are less than that at the dry cutting case in constant spindle speed. Same condition gets it at constant feed rate, as made clear in Figure (6). Minimum (Ra) $\operatorname{was}(0.57 \mu \mathrm{m})$ in $(\mathrm{f}=0.2 \mathrm{~mm} / \mathrm{rev})$ and $(\mathrm{N}=550 \mathrm{rpm})$. This indicates that the cutting fluid has high thermal conductivity and specific heat effectiveness in reducing the heat generated during the process, thereby reducing the temperature of samples, according to reference [13]. The blending oil and water were widely used to remove the hot chip from cutting region, which was a very important factor in heat elimination, agree with reference [14].

\section{Conclusion}

1. Through the results obtained it was found that cutting conditions have a significant impact on the surface roughness especially spindle speed and feed rate. The minimum surface roughness have been obtained at high spindle speed and low feed rate at wet cutting case.

2. The cooling fluid is supplied with a protective layer so that it can protect the alloy's surface from high temperature during the turning operation.

3. Generally, the study proved that the feed rate has a significant effect and then the spindle speed by using the cooling fluid and dry cutting, too.

4. With coolant and appropriate cutting conditions, the least surface roughness and best quality of metal surface can be obtained under any operations.

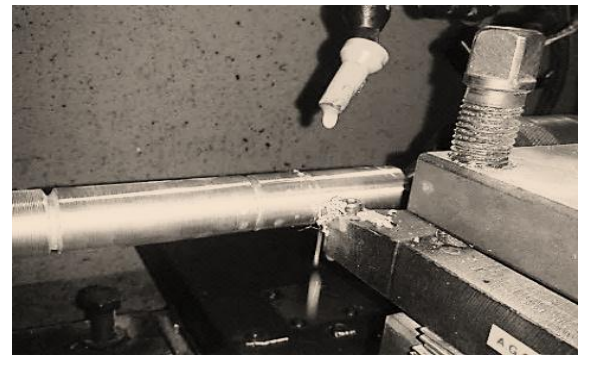

(a)

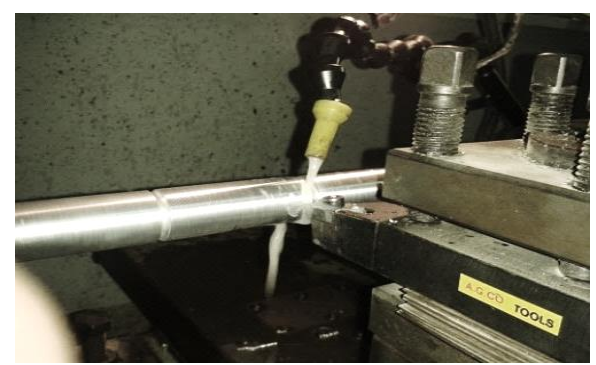

(b)

Fig. 1: Machining surfaces: (a) dry cutting (b) wet cutting 
Journal of University of Babylon for Engineering Sciences, Vol. (26), No. (7): 2018.

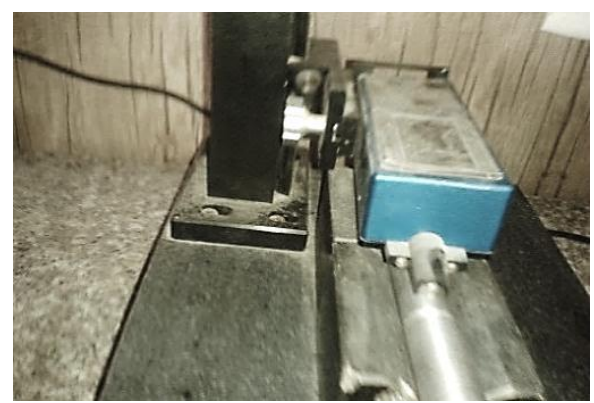

Fig. 2: Surface roughness device.

Table 1: Chemical composition of Aluminum alloy2024.

\begin{tabular}{|c|c|c|c|c|c|c|c|}
\hline Element & $\mathrm{Cu}$ & $\mathrm{Fe}$ & $\mathrm{Mn}$ & $\mathrm{Cr}$ & $\mathrm{Si}$ & $\mathrm{Mg}$ & $\mathrm{Al}$ \\
\hline percentage & 4.16 & 0.50 & 0.97 & 0.05 & 0.27 & 0.65 & 92.1 \\
\hline
\end{tabular}

Table 2: Properties of cooling fluid.

\begin{tabular}{|c|c|c|c|}
\hline Density $\rho$ & Viscosity $v$ & Acid level $\mathrm{pH}$ & Corrosion level \\
\hline $1.04525 \mathrm{~kg} / \mathrm{m}^{3}$ & $0.1696 \mathrm{mpa}$ & 7.5 & Create protect layer \\
\hline
\end{tabular}

1. Dry case:

a. Constant spindle speed

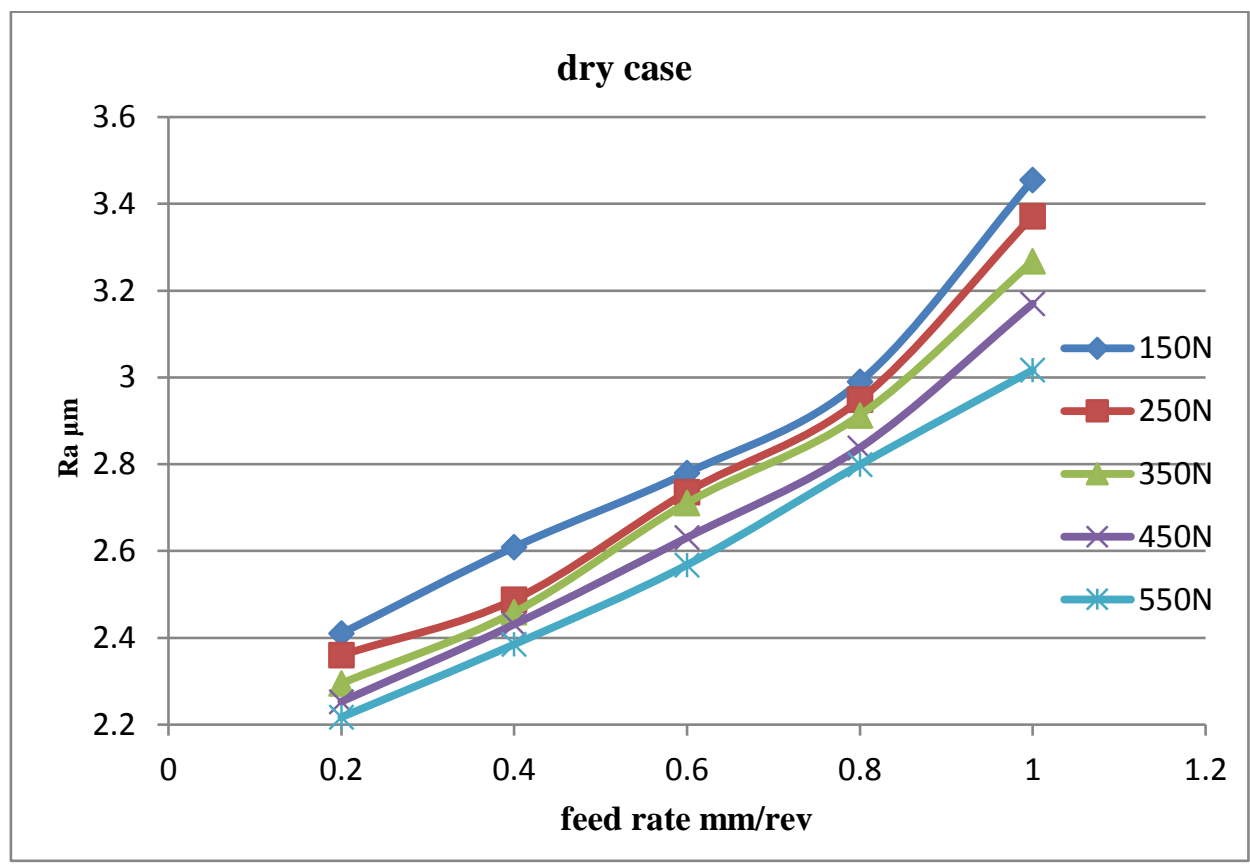

Fig. 3: Surface roughness vs feed rata at dry case. 
Journal of University of Babylon for Engineering Sciences, Vol. (26), No. (7): 2018.

b. Constant feed rate.

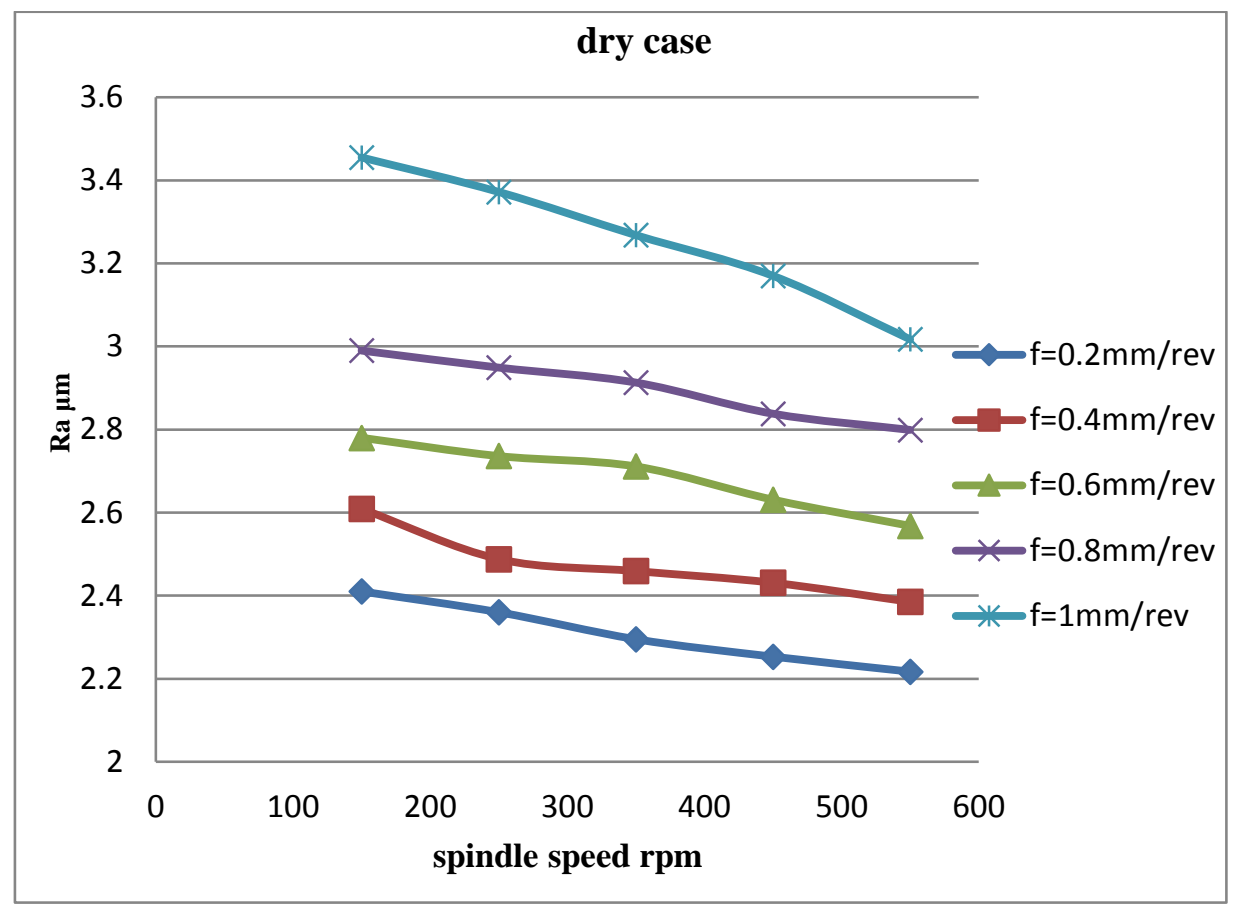

Fig. 4: surface roughness vs spindle speed at dry case.

2. Wet case:

a. Constant spindle speed.

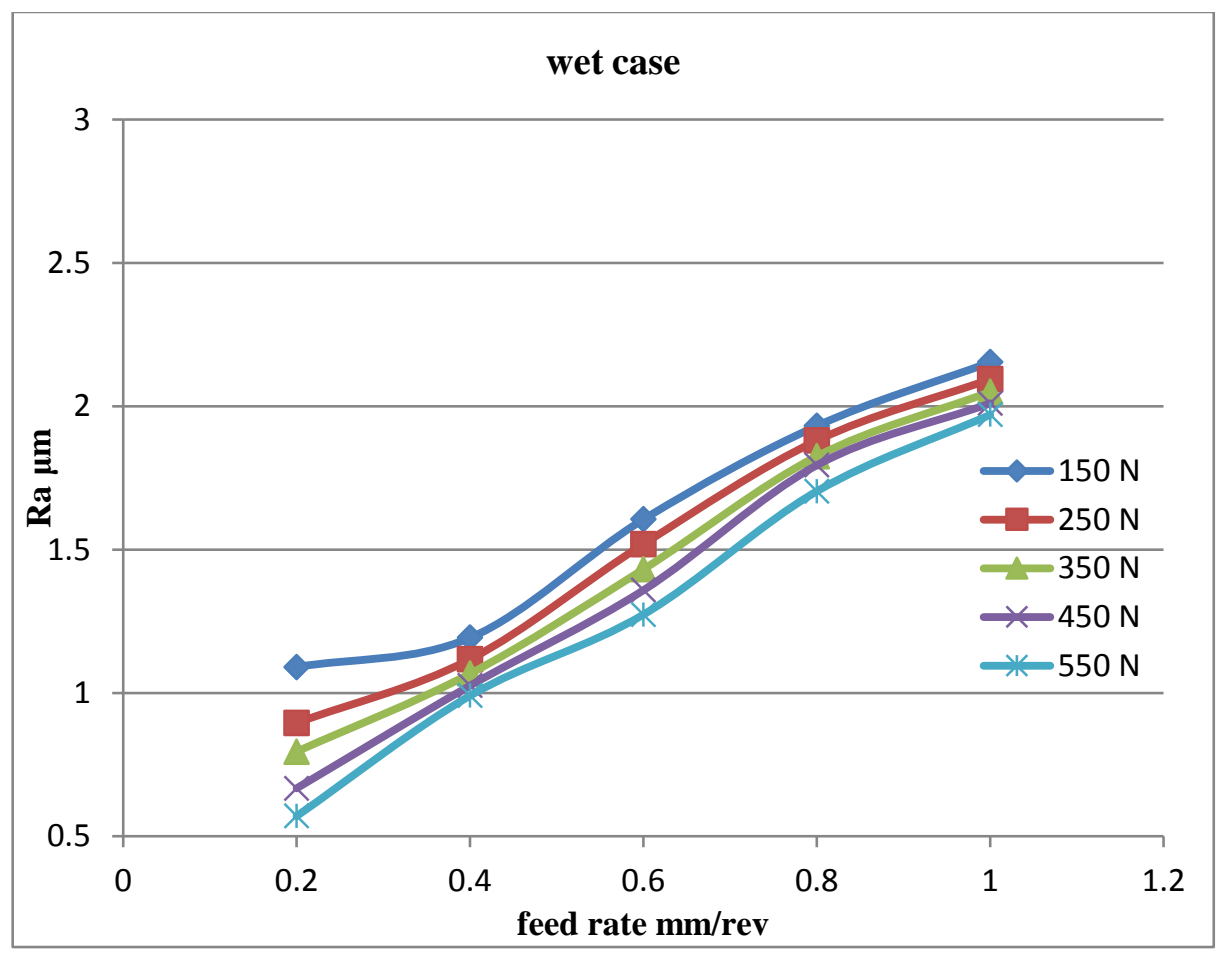

Fig. 5: Surface roughness vs feed rate at wet case. 


\section{b. Constant feed rate.}

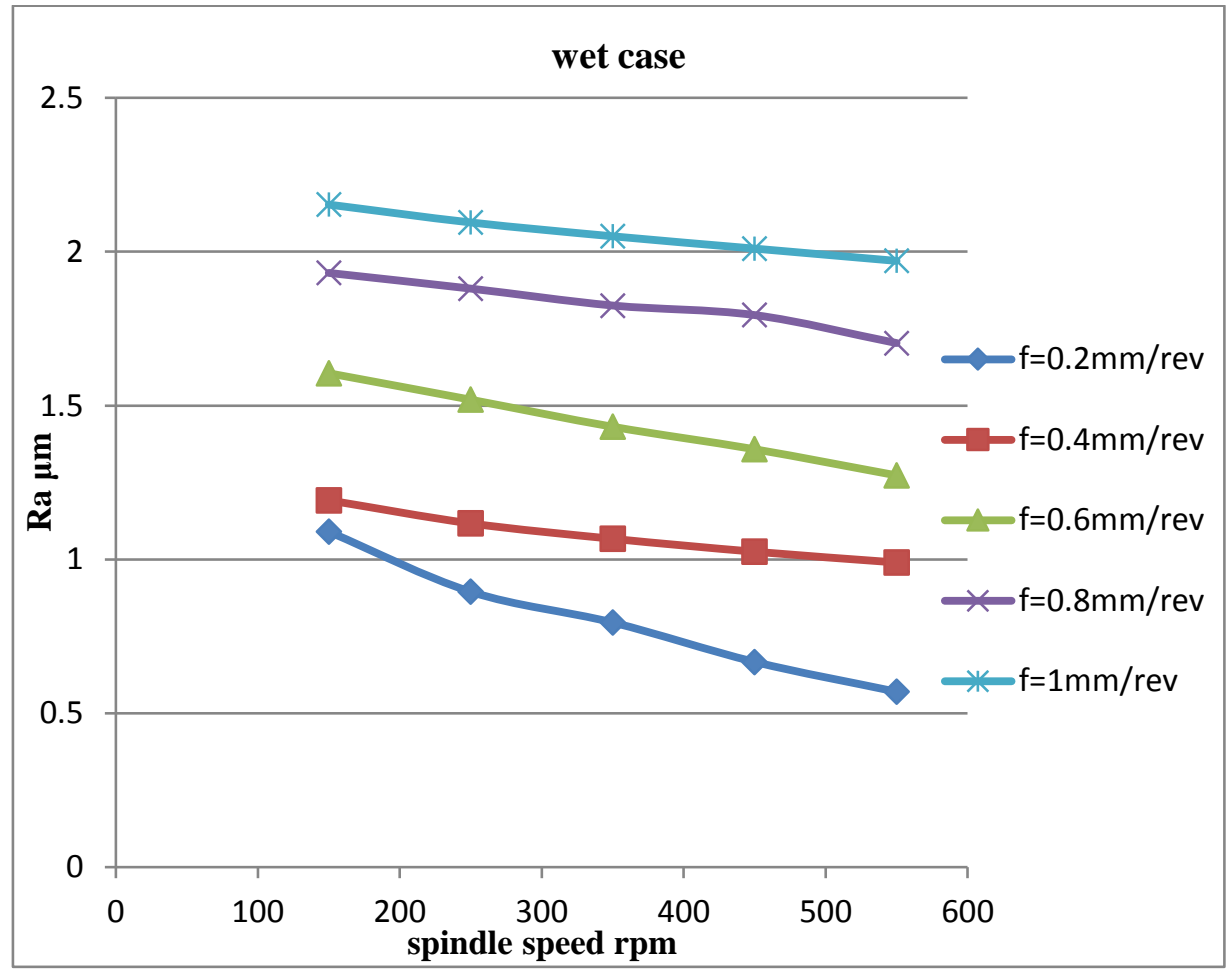

Fig. 6: Surface roughness vs spindle speed at wet case.

\section{Referances}

[1] George E. Dieter, Mechanical Metallurgy. ISBN 0-07-100406-8. PP. 693-694, printed in Singapore, 1988.

[2] Serope Kalpakjian and Steven R. Schmid, Manufacturing Engineering and Technology. Fourth edition published by Dorling Kindersley New Delhi (India). ISBN 978-81-170-6. PP. 892-898, 2006.

[3] Kuram E., Ozcelik B., Demirbas E. Sik, "Effect of the Cutting Fluid types and Cutting Parameters on Surface Roughness and Thrust Force", Proceedings of the Word Cogress on Engineering, Vol. 2, London, U. K. PP. 1312-1315, 2010.

[4] Basim A. Khidhir, Bashir Mohamed, "Study of Cutting Speed on Surface Roughness and Chip Formation", Journal of Mechanical Science and Technology, Vol. 24, No. 5. PP. 1053-1059, 2010.

[5] Mathew A. Kuttolamadom, Sina Hamzehlouia, M. Laine Mears, "Effect of Machining Feed on Surface Roughness in Cutting 6061Aluminum" International Center for Automotive Research, Clemson University, copy right SAE International. PP. 1-19, 2010.

[6] Tulasiramarao B., Dr. K. Srinivas, Dr. Pram Reddy, A. Raveendra, Dr. B. V. R. Ravi Kuumar, "Experimental Study on the Effect of Cutting Parameters on Surface Finish Obtained in CNC Turning Operation", International Journal of Innovative Research in Science Enchineering and Technology, Vol. 2, Issue 9, ISSN: 23198753. PP. 4547-4554, 2013. 
Journal of University of Babylon for Engineering Sciences, Vol. (26), No. (7): 2018.

[7] Suhair Ghazi Hassein, "An Experimental Study of the Effects of Coolant Fluid on Surface Roughness in Turning Operation for Brass Alloy", Journal of Engineering, vol. 20, No. 3. PP. 96-104, 2014.

[8] Ahmed Basil Abdulwahhab, "A Study the Effect of (Cutting Speed, Feed rate and depth of cut) on Surface Roughness in the Milling Machining", Eng. and Tech. Journal, Vol.33, part (A), No. 8. PP.1785-1797, 2015.

[9] Hemaid A., Tarik Tawfeek, Ibrahim A. A., "Experimental Investigation on Surface Finish during Turning of Aluminum under Dry and Minimum Quantity Lubrication Machining", American Journal of Materials and Technology, Vol.4, No. 1. PP. 1-5, 2016.

[10] Khalid Ahmed Al-Dolaimy, "Effect of Cutting Parameters on Surface Roughness in Turning Operations", Al- Qadisiyah Journal for Engineering Science, Vol. 9, No. 4. PP. 442-448, 2016.

[11] Wavdhane Yogesh G, Sonavane Prasad R, Pawar, Umesh A, Prof. Pathan"Effect of Coolant on Surface Roughness and Tool Life during Turning", International Conference on Emerging Trend in Engineering and Management Research (ICETEMR), ISBN: 978-81-932074-7-5. PP. 943, 2016.

[12] Suker D. K., Alsoufi M. S., Alhusaini M. M., Azam S. A., "Study the Effect of Cutting Conditions in Turning Process on Surface Roughness for Different Materials", Word Journal of Research and Review, Vol. 2, Issue 4. PP. 16-21, 2016.

[13] Mike II P. Groover, Introduction to Manufacturing Processes. ISBN 978-0-47063228-4, page 418, printed in the United States of America, 2012.

[14] Black J. T., Ronald A. Kohser, Materials and Processes in Manufacturing. Society of manufacturing engineering, ISBN 978-0470-05512-0, PP. 591-594, 2007. 
Journal of University of Babylon for Engineering Sciences, Vol. (26), No. (7): 2018.

\section{تأثير ظروف القطع وسائل التبريد على خشونة السطح الأمنيوم AA2024في عملية الخر اطة وفاء مهدي جودي قسم هندسة الدعادن، كلية هندسة الدواد، جامعة بابل، بابل، العر/ق. wafamahdi55@yahoo.com}

الخلاصة

في هذا البحث تم دراسة تأثثر كل من ظروف القطع وسائل التبريد على خشونة السطح لسبيكة المنيوم

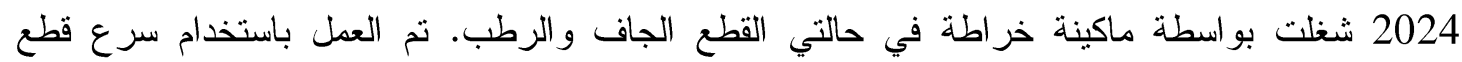
ومعدلات تغذية مختلفة مع بقاء عمق القطع ثابت، سائل التبريد المستعمل هو ماء مستحلب مكون من (ماء + زيت). اثبتت النتائج ان لظروف القطع وسائل الثبريد تأثير واضح لبقاء السطح بأقل خشونة (Ra) ممكنة حتى في حالة القطع الجاف. من ناحية اخرى اظهرت النتائج ان لمعدل التغذية تأثير أكثر من سرعة القطع باء الدور انية. الكلمات المفتاحية: - خشونة السطح، عملية خر اطة، سائل تبريد وظروف القطع. 